Toshihito Tsubo MD, Tsuyoshi Kudo MD, Akitomo Matsuki MD, Tsutomu Oyama MD

\title{
Decreased glucose utilization during prolonged anaesthesia and surgery
}

We studied the influence of prolonged anaesthesia and surgery on glucose metabolism by means of the euglycaemic insulin clamp method in eight patients who underwent prolonged surgery. Eleven patients who underwent surgery of short duration served as a control group. Plasma concentrations of catabolic hormones were measured simulianeously. Glucose urilization during prolonged anaesthesia, $(P A)$ group, was lower than that in the control group $(P<0.0 I)$ (glucose utilization $7.59 \pm 0.73 \mathrm{mg} \cdot \mathrm{kg}^{-1} \cdot \mathrm{hr}^{-1}$ in the control group vs $4.03 \pm$ $0.71 \mathrm{mg} \cdot \mathrm{kg}^{-1} \cdot \mathrm{hr}^{-1}$ in PA group respectively). There were no significant differences in plasma catecholamine and glucagon concentrations between the PA and control groups. Plasma-free fatty acid levels increased significantly in the PA group before the euglycaemic insulin clamp (free fatty acid level: $0.496 \pm$ $0.053 \mathrm{mmol} \cdot L^{-1}$ in the control group, vs $0.834 \pm 0.103 \mathrm{mmol} \cdot \mathrm{L}^{-1}$ in the PA group at the pre-clamp period, $P<0.01$ ). Tissue resistance to exogenous insulin increased during prolonged anaesthesia and surgery although there were no significant changes in plasma catabolic hormone levels.

On a étudié l' influence de l'anesthésie prolongée et la chirurgie sur le métabolisme du glucose en utilisant le test "Euglycaemic insulin clamp method" chez huit patients devant subir une chirurgie prolongée. Onze patients devant subir une chirurgie de courte durée ont servi comme groupe contrôle. Les concentrations plasmatiques des hormones de catabolisme ont été mesurées simultanément. L'utilisation du glucose durant l'anesthésie prolongée $(P A)$, dans le groupe $P A$, était plus basse que celle du groupe contrôle $(P<0.01)$ (l'utilisation du glucose $7,59 \pm 0,73$ $\mathrm{mg} \cdot \mathrm{kg}^{-1} \cdot \mathrm{hre}^{-1}$ pour le groupe contrôle versus $4,03 \pm 0,71$ $\mathrm{mg} \cdot \mathrm{kg}^{-1} \cdot \mathrm{hre}^{-1}$ dans le groupe PA). Il n'y avait aucune

\section{Key words}

ANAESTHESIA: duration; HORMONES: catecholamine, insulin, glucagon; MEASUREMENT TECHNIQUES: euglycaemic insulin clamp; METABOLISM: fatty acids, glucose.

From the Department of Anaesthesiology, University of Hirosaki School of Medicine, 036 Hirosaki, Japan.

Address correspondence to: $\mathrm{Dr}$. T. Tsubo. différence significative dans les catécholamines plasmatiques et les contractions de glucagon entre le groupe PA et le groupe contrôle. Le taux d'acide gras plasmatique libre a augmenté significativement dans le groupe PA avant le test de «Euglycaemic insulin clamp " (taux d'acide gras libre: $0,496 \pm$ $0,053 \mathrm{mmol} \cdot L^{-1}$ pour le groupe contrôle versus $0,834 \pm 0.103$ $\mathrm{mmol} \cdot \mathrm{L}^{-1}$ dans le groupe $P A$ pour la période pré-clampage, $P<0,01)$. La résistance tissulaire d̀ l'insuline exogène a augmenté durant l'anesthésie prolongée et la chirurgie même s'il n'y avait aucun changement significatif dans le niveau des hormones de catabolisme.

Glucose metabolism is disturbed during anaesthesia and surgery. ${ }^{1.2}$ The duration of surgery is an important factor for morbidity and mortality in critical patients. ${ }^{3}$ However, there are no available reports describing the influence of the duration of anaesthesia and surgery on glucose metabolism.

The euglycaemic insulin clamp method is a method using a maximally effective dose of insulin to determine tissue insulin resistance. ${ }^{4}$ This study aimed to evaluate the effect of prolonged anaesthesia and surgery on glucose metabolism using this method in minor surgical procedures. Changes in plasma catabolic hormone levels were also determined.

\section{Methods}

Approval for the study was given by the Ethics Committee and informed consent was obtained from all subjects. Eight patients who underwent prolonged anaesthesia (PA) were the subjects of the study (Table I). Eleven patients who underwent short surgical procedures were chosen as controls. Surgical procedures included plastic and orthopaedic in the control group and the same together with vessel anastomosis in the PA group. Preoperative laboratory tests failed to show any dysfunction in the liver, kidney, and endocrine systems.

All patients fasted for eight hours and received $10 \mathrm{mg}$ diazepam PO $1.5 \mathrm{hr}$ before anaesthesia. Anaesthesia was induced with thiopentone $4 \mathrm{mg} \cdot \mathrm{kg}^{-1}$ and succinylcholine I $\mathrm{mg} \cdot \mathrm{kg}^{-1}$ IV. Anaesthesia was maintained with enflu- 
TABLE I Patient characteristics

\begin{tabular}{lll}
\hline & Conirol & Prolonged anaesthesia \\
\hline Number of patients & 11 & 8 \\
Sex - Female & 4 & 3 \\
$\quad$ - Male & 7 & 5 \\
Age (yrs) & $34.4 \pm 4.8$ & $39.6 \pm 8.2$ \\
Weight (kg) & $57.1 \pm 3.2$ & $56.9 \pm 3.8$ \\
Duration of anaesthesia (h) & $3.2 \pm 0.2$ & $13.0 \pm 1.0^{*}$ \\
\hline
\end{tabular}

All values are mean $\pm S E M$.

$* P<0.01$.

rane (1.5 MAC) in nitrous oxide ( 50 per cent) and oxygen (50 per cent). The lungs were ventilated and end-tidal $\mathrm{CO}_{2}$ was maintained in the normal range. Pancuronium was given for muscle relaxation. Lactated Ringer's solution was infused at a rate of $6 \mathrm{ml} \cdot \mathrm{kg}^{-1} \cdot \mathrm{hr}^{-1}$. No glucose was administered until the start of the clamp test. Blood loss during the euglycaemic clamp ranged from 15 to $100 \mathrm{ml}$ which was replaced with three times the volume of lactated Ringer's solution.

Electrocardiogram, end-tidal $\mathrm{CO}_{2}$ and inspiratory oxygen concentrations were monitored using Multi-Super 2F21A and Respina (Nihonkoden-Sanei Co) throughout the procedure. Direct arterial and central venous pressures were also measured through catheters placed in the left radial artery and right internal jugular vein in the PA group. An 18-gauge indwelling catheter was inserted in the saphenous or cephalic vein for two-minute interval glucose measurements. Blood glucose concentration was determined automatically by the glucose oxidaze method with Glucose Monitor GM-1320 ( Kyoto Daiichi Kagaku). Urine volume, and urinary ketone body and glucose concentrations were measured during the procedure.

The euglycaemic insulin clamp test was performed at the start of surgery in the control group and at seven hours after the start of surgery in the PA group. In the euglycaemic insulin clamp technique, plasma insulin concentration is increased acutely and maintained above $200 \mu \mathrm{U} \cdot \mathrm{ml}^{-1}$ by a bolus and continuous infusion of insulin. The blood glucose concentration is maintained at the basal levels by an infusion of glucose. Under these conditions of euglycaemia and high plasma insulin concentration, the glucose infusion rate equals the glucose uptake by all body tissues. The rate of glucose infusion during the 80 to $120 \mathrm{~min}$ from the start of the insulin and glucose infusion was adopted as the glucose utilization and this glucose utilization became a measure of tissue sensitivity to exogenous insulin.

A priming dose of regular insulin was given IV over ten seconds to increase the insulin concentration rapidly above $200 \mu \mathrm{U} \cdot \mathrm{ml}^{-1}$ at the beginning of the clamp. The priming dose was calculated as: insulin bolus $(\mathrm{mU})=$

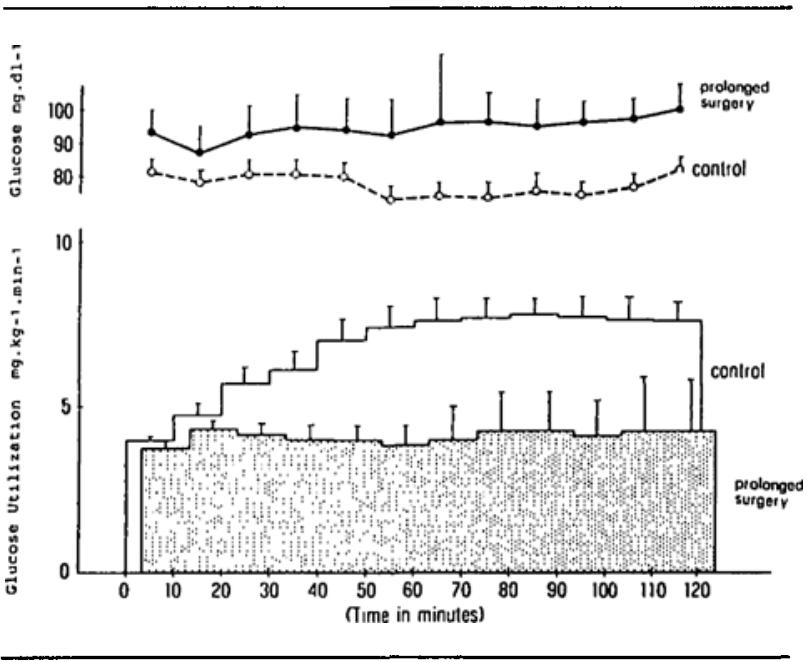

FIGURE Changes in blood glucose concentration and glucose utilization during euglycaemic clamp.

distribution volume $\left(100 \mathrm{ml} \cdot \mathrm{kg}^{-1} \times\right.$ body weight, $\left.\mathrm{kg}\right) \times$ desired increment in plasma insulin $\left(\mu \mathrm{U} \cdot \mathrm{ml}^{-1}\right) / 1000$. Constant intravenous infusion of insulin followed at a rate of $5 \mathrm{mU} \cdot \mathrm{kg}^{-1} \cdot \mathrm{min}^{-1}$. Insulin (Actrapid, Novo) was dissolved in 0.9 per cent sodium chloride as a 2 $\mathrm{U} \cdot \mathrm{ml}^{-1}$ solution. In $50 \mathrm{~kg}$ patients $32.5 \mathrm{U}$ insulin was administered using these methods. It was ensured that plasma insulin concentration was high enough for the clamp test after the procedure.

Automatic monitoring of blood glucose concentrations at two-minute intervals was achieved from ten minutes before the start of the euglycaemic insulin clamp. Glucose was administered as a 50 per cent solution with a syringe pump. Adjustments of the glucose infusion rate were made manually according to the change in blood glucose concentration. Average glucose infusion doses were 46.5 $\pm 3.3 \mathrm{~g}$ in control group and $26.2 \pm 2.5 \mathrm{~g}$ in PA group. Potassium chloride was infused at a rate of $5 \mathrm{mEq} \cdot \mathrm{hr}^{-1}$ to prevent hypokalaemia.

Six blood samples were obtained from each subject as follows: before induction of anaesthesia, before clamp, $30,60,90$ and $120 \mathrm{~min}$ after the clamp. The six $\mathrm{ml}$ of venous blood were separated within 15 min with a refrigerated centrifuge and stored at $-70^{\circ} \mathrm{C}$ until measurement. Plasma catecholamine concentrations were measured by gas chromatography. ${ }^{5}$ Plasma insulin and glucagon concentrations were determined by radioimmunoassay. ${ }^{6,7}$ Plasma-free fatty acid was determined by the enzymatic method.

All results are presented as mean \pm SEM. An unpaired Student's t test was used for intergroup comparisons while one-way analysis of variance was used to compare the values within a group. Probability values less than 0.05 were considered to be significant. 
TABLE II Changes in hormone concentrations

\begin{tabular}{|c|c|c|c|c|c|c|c|}
\hline & & Pre-anaesth & Pre-clamp & Clamp $-30 \mathrm{~min}$ & Clamp $-60 \min$ & Clamp $-90 \mathrm{~min}$ & Clamp $-120 \mathrm{~min}$ \\
\hline $\begin{array}{l}\text { Epinephrine } \\
\left(\mathrm{pg} \cdot \mathrm{m}^{-1}\right)\end{array}$ & $\begin{array}{l}\text { Control } \\
\text { Prolonged }\end{array}$ & $\begin{array}{l}64.0 \pm 12.0 \\
82.7 \pm 14.0\end{array}$ & $\begin{array}{l}53.9 \pm 8.2 \\
86.0 \pm 16.6\end{array}$ & $\begin{array}{l}76.6 \pm 20.3 \\
89.0 \pm 19.3\end{array}$ & $\begin{array}{l}47.5 \pm 4.4 \\
88.3 \pm 25.1\end{array}$ & $\begin{array}{l}70.3 \pm 7.0 \\
73.2 \pm 18.0\end{array}$ & $\begin{array}{l}58.1 \pm 6.8 \\
56.7 \pm 16.7\end{array}$ \\
\hline $\begin{array}{l}\text { Norepinephrine } \\
\left(\mathrm{pg} \cdot \mathrm{ml}^{-1}\right)\end{array}$ & $\begin{array}{l}\text { Control } \\
\text { Prolonged }\end{array}$ & $\begin{array}{l}130.6 \pm 22.0 \\
186.2 \pm 36.0\end{array}$ & $\begin{array}{l}146.5 \pm 16.4 \\
188.6 \pm 33.1\end{array}$ & $\begin{array}{r}129.4 \pm 19.9 \\
209.0 \pm 56.6\end{array}$ & $\begin{array}{l}112.6 \pm 17.6 \\
271.5 \pm 72.3\end{array}$ & $\begin{array}{l}164.4 \pm 28.0 \\
258.0 \pm 79.1\end{array}$ & $\begin{array}{l}181.9 \pm 31.5 \\
145.3 \pm 37.9\end{array}$ \\
\hline $\begin{array}{l}\text { Insulin } \\
\quad\left(\mu \mathrm{U} \cdot \mathrm{ml}^{-1}\right)\end{array}$ & $\begin{array}{l}\text { Control } \\
\text { Prolonged }\end{array}$ & $\begin{array}{l}20.5 \pm 2.7 \\
19.1 \pm 1.8\end{array}$ & $\begin{array}{l}16.4 \pm 4.6 \\
10.9 \pm 1.9\end{array}$ & $\begin{array}{l}626.6 \pm 70.1 \dagger \\
588.7 \pm 222.2 \dagger\end{array}$ & $\begin{array}{l}680.4 \pm 77.2 \dagger \\
529.0 \pm 127.6 \dagger\end{array}$ & $\begin{array}{l}697.0 \pm 113.5 \dagger \\
608.9 \pm 191.2 \dagger\end{array}$ & $\begin{array}{l}677.4 \pm 164.4 \dagger \\
457.2 \pm 23.1 \dagger\end{array}$ \\
\hline $\begin{array}{l}\text { Glucagon } \\
\qquad\left(\mathrm{pg} \cdot \mathrm{ml}^{-1}\right)\end{array}$ & $\begin{array}{l}\text { Control } \\
\text { Prolonged }\end{array}$ & $\begin{array}{r}81.6 \pm 13.7 \\
111.6 \pm 24.6\end{array}$ & $\begin{array}{c}99.4 \pm 6.4 \\
101.6 \pm 14.5\end{array}$ & $\begin{array}{l}74.4 \pm 9.0 \\
74.7 \pm 12.2\end{array}$ & $\begin{array}{l}75.8 \pm 9.9 \\
78.0 \pm 9.9\end{array}$ & $\begin{array}{l}81.9 \pm 10.9 \\
74.5 \pm 10.8\end{array}$ & $\begin{array}{l}86.3 \pm 16.2 \\
93.7 \pm 0.7\end{array}$ \\
\hline $\begin{array}{l}\text { FFA } \\
\quad\left(\mathrm{mmol} \cdot \mathrm{L}^{-1}\right)\end{array}$ & $\begin{array}{l}\text { Control } \\
\text { Prolonged }\end{array}$ & $\begin{array}{l}0.425 \pm 0.052 \\
0.403 \pm 0.048\end{array}$ & $\begin{array}{l}0.496 \pm 0.053 \\
0.834 \pm 0.103 \dagger \ddagger\end{array}$ & $\begin{array}{l}0.275 \pm 0.027^{*} \\
0.243 \pm 0.092\end{array}$ & $\begin{array}{l}0.215 \pm 0.021 \dagger \\
0.199 \pm 0.031 \dagger\end{array}$ & $\begin{array}{l}0.204 \pm 0.013 \\
0.155 \pm 0.030 \dagger\end{array}$ & $\begin{array}{l}0.246 \pm 0.031 \\
0.170 \pm 0.058 \dagger\end{array}$ \\
\hline
\end{tabular}

All values are mean $\pm S E M$.

$* P<0.05$ compared with pre-anaesthetic value.

$\dagger P<0.01$

$\ddagger P<0.01$ compared with control group.

\section{Results}

The changes in blood glucose concentration and the doses of glucose administration are shown in the Figure. The level of blood glucose was higher in the prolonged anaesthesia (PA) group $(P<0.05)$. The glucose utilization was $4.03 \pm 0.71 \mathrm{mg} \cdot \mathrm{kg}^{-1} \cdot \mathrm{min}^{-1}$ in the PA group and $7.59 \pm 0.73 \mathrm{mg} \cdot \mathrm{kg}^{-1} \cdot \mathrm{min}^{-1}$ in the control group $(P$ $<0.01$ ).

Plasma insulin level was over $200 \mu \mathrm{U} \cdot \mathrm{ml}^{-1}$ in all patients after the start of the clamp test (Table U). No significant differences were seen in plasma catecholamine and glucagon concentrations between the control and PA groups. Plasma-free fatty acid concentration increased significantly at the start of the glucose clamp in the PA group. However, the free fatty acid level decreased promptly after glucose and insulin administration. There was no increase in blood lactate level during the procedures. Neither urinary glucose nor ketone bodies were detected during anaesthesia and surgery.

\section{Discussion}

Glucose intolerance during anaesthesia and surgery is induced by such factors as impaired insulin secretion, diminished peripheral glucose oxidation, decreased biological response of tissues to insulin and increased hepatic glucose output. ${ }^{8}$ This study was undertaken to evaluate the change in tissue resistance to insulin. Previous methods for assessing insulin resistance have depended on only one insulin dose or concentration and may underestimate or fail to demonstrate the presence of insulin resistance. ${ }^{9}$

The euglycaemic insulin clamp test, introduced by Defronzo, ${ }^{4}$ was utilized to estimate the tissue sensitivity to insulin. In this technique, plasma insulin concentration is increased acutely and maintained above $200 \mu \mathrm{U} \cdot \mathrm{ml}^{-1}$ by the continuous infusion of insulin. Glucose production from the liver is completely suppressed when plasma insulin concentration is over $60 \mu \mathrm{U} \cdot \mathrm{ml}^{-1}$ and the maxi$\mathrm{mal}$ glucose utilization occurs at insulin concentrations of 200-700 $\mu \mathrm{U} \cdot \mathrm{ml}^{-1} .9$ It takes two hours to accomplish the test and we cannot repeat the method during anaesthesia due to the long elimination time of insulin. Therefore, we compared the value of PA group with that of control group.

There is much controversy how anaesthesia affects glucose metabolism. Many anaesthetic agents have no influence on blood glucose and plasma insulin concentrations. Oyama $e t$ al. ${ }^{10}$ reported that enflurane anaesthesia for $45 \mathrm{~min}$ did not affect the plasma insulin, growth hormone and blood glucose concentrations. The insulin response to exogenous glucose was inhibited during enflurane anaesthesia in the dog. " Diminished insulin release from pancreatic islets has been demonstrated for enflurane. ${ }^{12}$ Penicaud et al. ${ }^{13}$ reported that glucose utilization of the postural muscles decreased in rats anaesthetized with pentobarbitone.

Mild surgical intervention such as cholecystectomy with inhalational anaesthesia is associated with an increase in circulating catecholamines, hyperglycaemia and impaired insulin secretion. Ishihara $e t$ al. ${ }^{14}$ reported that the insulin response to a glucose infusion was decreased by 15 per cent during surgery. Kuntshen et al. ${ }^{15}$ described the decrease of glucose utilization during cardiopulmonary bypass using the euglycaemic clamp. No change in the red blood cell insulin receptor was reported during mild surgical stress. ${ }^{16}$

Minor surgical procedure did not affect plasma concentrations of catabolic hormones. ${ }^{17}$ In this investigation, we 
selected patients undergoing only minor surgery to observe the effect of the duration of anaesthesia and surgery without strong surgical stimulation. There are few reports discussing the influence of the duration of anaesthesia and surgery on endocrine function. Tanioka ${ }^{18}$ found no differences in plasma cortisol, glucose and free fatty acids levels between two and six hours after the start of surgery. However, his patients mainly underwent major abdominal surgery.

Epinephrine stimulates hepatic glucose output, reduces glucose utilization and inhibits insulin secretion. ${ }^{19}$ In addition, it decreases the tissue response to insulin. ${ }^{8}$ However, there were no significant changes in plasma catecholamine levels in this study even during prolonged procedures. It has been reported that enflurane anaesthesia effectively blocked the sympathetic response to surgical stress. ${ }^{20}$

Glucagon induces hyperglycaemia and increases plas$\mathrm{ma}$ insulin concentration. Glucose utilization is augmented by the administration of glucagon. Plasma glucagon level did not change during anaesthesia and surgery. Administration of insulin decreases the plasma glucagon level. ${ }^{2}$ A gradual decrease in glucagon level during the euglycaemic clamp has been reported in awake healthy and uraemic subjects. ${ }^{21}$ However, no significant decrease of glucagon concentration was found in this study. Other factors which stimulate glucagon secretion such as cortisol may be involved.

The increase in plasma-free fatty acid seemed to be due to surgical stress and starvation, because patients in the PA group had no caloric intake for about $20 \mathrm{hr}$ until the start of the euglycaemic clamp. Intraoperative glucose infusion at rates of $12.5 \mathrm{~g} \cdot \mathrm{hr}^{-1}$ decreases blood-free fatty acid. ${ }^{22}$ Free fatty acid competes with glucose uptake mainly by skeletal and myocardial muscle. ${ }^{23}$

The reason for resistance to exogenous insulin in prolonged anaesthesia and surgery is unclear and further investigation is needed.

\section{References}

1 Walsh ES, Traynor C, Paterson JL et al. Effect of different intraoperative fluid regimens on circulating metabolites and insulin during abdominal surgery. Br J Anaesth 1983; 55: 135-9.

2 Kehlet $H$, Moller $l b W$. The effects of regional anaesthesia on the endocrine-metabolic response to surgery. In: Oyama (Ed.). Endocrinology and the Anaesthetist. Amsterdam: Elsevier Science Publishers B.V., 1983; 23-35.

3 Steen PA, Tinker JH, Tarhan S. Myocardial reinfarction after anesthesia and surgery. JAMA 1978; 239: 256670.
4 Defronzo RA, Tobin JD, Andres $R$. Glucose clamp technique: a method for quantifying insulin secretion and resistance. Am J Physiol 1979; 237: E2 14-23.

5 Hallman $H$, Farnebo LO, Hamberger $B$ et al. A sensitive method for determination of plasma catecholamines using liquid chromatography with electrochemical detection. Life Sci 1978; 23: 1049-52.

6 Herbert V, Lau KS, Gottlieb CW, Bleicher SJ. Coated charcoal immunoassay of insulin. J Clin Endocrinol Metab 1965; 25: 1375-84.

7 Heading LG. Radioimmunological determination of pancreatic and gut glucagon in plasma. Diabetologia 1971; 7: 10-9.

8 Diltoer $M$, Camu $F$. Glucose homeostasis and insulin secretion during isoflurane anesthesia in humans. Anesthesiology 1988; 68: 880-6.

9 Rizza RA, Mandarino LJ, Gerich JE. Dose-response characteristics for effects of insulin on production and utilization of glucose in man. Am J Physiol 1981; 240: E630-9.

10 Oyama T, Matsuki A, Kudo M. Effects of enflurane (Ethrane) anaesthesia and surgery on carbohydrate and fat metabolism in man. Anaesthesia 1972; 27: 179-84.

11 Ishihara H. Kallus FT, Giesecke Jr AH. Intravenous glucose tolerance test during anaesthesia in dogs: insulin response and glucose clearance. Can J Anaesth 198I; 28: 38I-5.

12 Ewart RBL, Rusy $B F$, Bradford $M W$. Effects of enflurane on release of insulin by pancreatic islets in vitro. Anesth Analg 1981; 60: 878-84.

13 Penicaud L, Ferre $P$, Kande J et al. Effect of anaesthesia on glucose production and utilization in rats. Am J Physiol 1987; 252: E365-9.

14 Ishihara $H$, Yao M, Aoyagi $N$ et al. Metabolic and endocrine response to abdominal surgery during phentolamine infusion in man. Jap J Anesth 1983; 32: 533-40.

15 Kuntschen FR, Galletti PM, Hahn C et al. Alteration of insulin and glucose metabolism during cardiopulmonary bypass under normothermia. J Thorac Cardiovasc Surg 1985; 89: 97-106.

16 Tsubo T, Kudo T, Kudo $M$ et al. The effect of anesthesia and surgery on human erythrocyte insulin receptor. Jap J Anesth 1987; 36: 1074-7.

17 Murakawa T, Satoh Y, Kudo T et al. Effects of sevoflurane anesthesia and surgery on glucose metabolism in man. Jap J Anesth 1987; 36: 1426-32.

18 Tanioka $F$, Ishihara $H$, Nagao $N$ et al. Effect of GIK and trimetaphan on glucose metabolism and peripheral circulation. Jap J Anesth 1988; 37: 933-7. 
19 Shamoon $H$, Hendler $R$, Sherwin RS. Synergistic interactions among antiinsulin hormones in the pathogenesis of stress hyperglycemia in humans. J Clin Endocrinol Metab 1981; 52: 1235-41.

20 Brown FF, Owens WD, Fels JA et al. Plasma epinephrine and norepinephrine levels during anesthesia: enflurane- $\mathrm{N}_{2} \mathrm{O}-\mathrm{O}_{2}$ compared with fentanyl $-\mathrm{N}_{2} \mathrm{O}-\mathrm{O}_{2}$. Anesth Analg 1982; 61: 366-70.

21 Schmitz O. Alberti KGMM, Christensen NJ et al. Aspects of glucose homeostasis in uremia as assessed by the hyperinsulinemic euglycemic clamp technique. Metabolism 1985; 34: 465-73.

22 Sieber FE, Smith DS, Kupferberg J et al. The effect of intraoperative glucose on protein catabolism and plasma glucose levels in patients with supratentrial tumor. Anesthesiology 1986; 64: 453-9.

23 Ferrannini E, Barrett EJ, Bevilacqua $S$ et al. Effect of fatty acids on glucose production and utilization in man. J Clin Invest 1983; 72: 1737-47. 